\title{
THE FIREARMS REFERENCE in the Alberta Court of Appeal
}

\section{DALE GiBSON}

If words were bullets, many victims would by now have been claimed by the incessant word-slinging between proponents and opponents of gun control ever since the Government of Canada first announced its intention to introduce the legislation that became the Firearms Act of 1995.' Words are not bullets, of course. So far, the chief consequence of the duelling among politicians, lobbyists, journalists, cocktail analysts, lawyers, and judges has been to slow the full implementation of the Act; and the only casualties have been those persons unlucky enough to get in the way of firearms discharges that the operation of effective gun control laws might have prevented.

In the celebrated "Shootout at the CA Corral" (Re Firearms Act (Canada) $)^{2}$, the Alberta Court of Appeal was as trigger-happy as the protagonists, firing off an estimated 122,000 words in the course of finding, by a majority of three to two, that the legislation is constitutionally valid. The essence of the majority's ruling seems likely to be upheld by the Supreme Court of Canada. A few of its words were wide enough off the mark in my opinion, however, to endanger innocent bystanders. Moreover, the probable confirmation of the Court of Appeal decision by the Supreme Court of Canada will not forestall the possibility of future raids from other directions.

This comment will not target every constitutional issue raised by the Firearms $A c t$ and the Court of Appeal decision. It will, after a brief overview of the litigation and the Court's voluminous reasons, set its sights on just three topics:

- the Court's treatment of the hoary and (one would have thought) familiar constitutional concept of "pith and substance";

- the possibility of a future challenge, based on Aboriginal rights as recognized and affirmed by s. $35(1)$ of the Constitution $\mathrm{Act}, 1982 ;^{3}$ and

Belzberg Fellow of Constitutional Studies, Faculty of Law, University of Alberta; Senior Counsel, Dale Gibson Associates, Public Law, Edmonton. The writer gratefully acknowledges the collaboration of Ritu Khullar of Chivers Greckol \& Kanee, Edmonton, in preparing the portion of the article concerning equality rights.

$1 \quad$ S.C. 1995, c. 39 [hereinafter Firearms Act]. A computer search in preparation for this comment turned up thirty-seven references in legal literature alone. Interestingly enough, only one of these deals with the constitutional dimension: A.C. Hutchinson \& D. Schneiderman, "Smoking Guns: The Federal Government Confronts The Tobacco and Gun Lobbies" (1995) Const. Forum 16. (1998), 164 D.L.R. (4th) 513 (Alta. C.A.) [hereinafter Firearms Reference].

Constitution Act, 1982, being Schedule B to the Canada Act 1982 (U.K.), 1982, c. 11 [hereinafter Constitution Act, 1982]. 
- the possibility of a future challenge based on equality rights guaranteed by $\mathbf{s}$. 15 of the Canadian Charter of Rights and Freedoms. ${ }^{4}$

\section{THE RAID}

The case came to the Alberta Court of Appeal by way of a constitutional reference made by Alberta's Lieutenant Governor-in-Council under the authority of s. 27 of the Judicature Act. ${ }^{5}$ The reference did not take aim at everything in the federal legislation; and it did not deploy every constitutional weapon available to opponents of the legislation. It sought only a declaration as to whether provisions of the Firearms Act (and related provisions of the Criminal Code) which require registration and licensing of what the reference referred to as "ordinary firearms" infringe "the jurisdiction of the Legislature of Alberta with respect to the regulation of property and civil rights pursuant to s. 92(13) of the Constitution Act, 1867." Presumably the Government of Alberta has no constitutional objection to federal regulation of weapons possessing greater potential destructiveness than the "ordinary firearms" that cause the overwhelming majority of firearm deaths in Canada. Presumably, too, it either saw no merit in the various Charter-based arguments that have been aimed at the legislation, or it decided to save those arguments for another day.

The federal gun control legislation in the United States, known as the "Brady Bill," was also under constitutional attack at the time the Alberta reference was made, and that attack was successful. The U.S. constitutional picture being very different than that of Canada's, however, (criminal law and the ultimate jurisdictional residue both belonging to the States, and a right to bear arms being constitutionally entrenched), it is not surprising that objections to the Brady Bill were very different than those raised by Alberta's challenge.

The Brady Bill required the federal Attorney General to institute, on a national basis, a system for scrutinizing the personal backgrounds of prospective handgun purchasers before purchase. This scheme was to be carried out by the chief law enforcement officer of each state and his or her respective staffs, and it was challenged on the ground that the federal Congress has no constitutional authority to impose such obligations on employees of the States. Although this objection eventually found favour with the Supreme Court of the United States ${ }^{7}$ (27 June 1997, after the Alberta reference was launched, but before it was heard by the Court of Appeal), and vital portions of the Brady Bill were accordingly struck down, a similar line of attack was not mounted in the Alberta reference, and would probably have failed if it had been raised.

Canadian Charter of Rights and Freedoms, Part I of the Constitution Act, 1982 being Schedule B to the Canada Act 1982 (U.K.), 1982, c. 11 [hereinafter Canadian Charter of Rights and Freedoms].

R.S.A. 1980, c. J-1.

Brady Handgun Violence Prevention Act, 1993, Pub. L. 103-159, 107 Stat. 1536, amending the Gun Control Act, 18 U.S.C. $\$ 921$ (1968).

Printz v. United States, 117 S. Ct. 2365 (1997). 
The Attorneys General of Manitoba, Saskatchewan, Northwest Territories and Yukon, along with national and Yukon pro-gun organizations, intervened in support of the Alberta Government's position that the impugned provisions are ultra vires. The Attorney General of Ontario did so as well, though with respect to registration, not to licensing.

Only two interveners - the Alberta Council of Women's Shelters, and a group known as the Coalition for Gun Control which included the cities of Toronto and Montreal and the Canadian Association of Chiefs of Police - entirely supported the challenged provisions. Their valiant supportive efforts helped the Court of Appeal's majority posse drive off the attackers of the legislative ranch - at least until the next raid is launched.

\section{CA TO THE RESCUE}

A three-member majority of the Alberta Court of Appeal - Chief Justice Fraser and Justices Hetherington and Berger - ruled in favour of the legislation. They held that the impugned provisions fell, in pith and substance, within the Parliament of Canada's jurisdiction over "criminal law" under s. 91(27) of the Constitution Act, 1867. Although they agreed in result, all three wrote separate Reasons for Judgment.

Chief Justice Fraser's Reasons opened with a succinct outline of the "paradox" she considered to have been placed before the Court:

Guns preserve lives; guns employ people; guns are used for legitimate recreational pursuits; and guns are the tools of some trades. At the same time, guns intimidate; guns maim; and guns kill. It is precisely because of this paradox - that guns are used for good as well as evil - that controversy surrounds government efforts at gun control. ${ }^{8}$

Her lengthy analysis of the constitutional aspects of that controversy included a history of the legislation and an outline of much that has been written about the need for it, as well as about its effectiveness. Her key conclusion, that the impugned provisions fall within the Parliament of Canada's jurisdiction with respect to "criminal law" under s. 91(27) of the Constitution Act, 1867, was not surprising, and seems likely to be upheld on appeal:

I regard the pith and substance of the licensing and registration provisions as being to protect public safety from the misuse of ordinary firearms, whether in crime or otherwise. In fact, it seems to me that effective gun control is doomed to failure without some proactive, preventative means of licensing and registering all firearms. Only upon knowing who has what guns will it be possible to reduce the likelihood that guns will be misused, whether criminally or otherwise.

[I]t seems to me that they are still sufficiently connected to a valid criminal purpose - the protection of the safety and security of Canadians. In the end, the licensing and registration provisions ultimately

Supra note 2 at para. 1.

Ibid. at para 208 [emphasis added]. 
make it more difficult for ordinary firearms to be misused, whether in crime or otherwise. That falls squarely within the federal criminal law power. ${ }^{10}$

This conclusion was supported by the separate concurring reasons of Hetherington and Berger J.J.A., and seems consonant with previous jurisprudence concerning the federal criminal law power, notably by the Supreme Court of Canada's 1995 decision in RJR-MacDonald Inc. v. Attorney General of Canada. "The latter decision involved federal legislative restrictions on tobacco advertising, for jurisdiction over which Parliament had relied on its "criminal law" power. The Supreme Court held, by a majority of seven to two, that Parliament was justified in doing so; although the restrictions were ultimately struck down on the ground that they violated freedom of expression under the Charter. On the "criminal law" issue, even the two dissenting judges, Major and Sopinka JJ., who thought that restrictions on tobacco advertising did not qualify as criminal law, agreed that the federal criminal law power includes the authority to prohibit conduct that involves "a significant and serious risk of harm or which cause significant and serious harm to public health, safety or security." 12 This decision led two prominent constitutional scholars, Allan Hutchinson and David Schneiderman, to conclude that "whatever (dubious) merit" the division of powers arguments advanced by opponents of the Firearms ACt "might have previously held now seems to have been effectively scotched by the Supreme Court's decision in RJRMacDonald."13 The Alberta Court of Appeal agreed, all three majority judges relying heavily on the RJR-MacDonald case.

Having reached that conclusion, the majority found it unnecessary to deal with the federal Government's alternative contention that the legislation is within Parliament's residual jurisdiction to make laws for the "peace, order and good government" of Canada.

The lengthy ${ }^{14}$ dissenting reasons, written by Conrad J.A. and concurred in by Irving J.A., concluded that the impugned provisions, in pith and substance, are about the provincial subject of "property and civil rights in the province" rather than about the federal subject of "criminal law." They disposed of the RJR-MacDonald decision as follows:

The majority of the Court accepted that smoking is proven to be dangerous to the health of Canadians. It recognized the difficulty of enforcing a prohibition against smoking but found that the promotion of tobacco through advertising was intimately related to its consumption. Advertising and encouraging others is a distinct, unsafe act separate from the unsafe act of smoking. Moreover, there was a direct link between the prohibited act and the harm sought to be curbed. The encouragement of smoking is conduct, in itself, harmful. Engaging in that harmful conduct is singled out as deserving of sanction. Unlike ordinary weapons, which have useful, necessary and important uses (in some cases for safety),

Ibid. at para. 248.

(1995), 127 D.L.R. (4th) 1 (S.C.C.) [hereinafter RJR-MacDonald].

Ibid. at para. 201.

Supra note 1 at 19 [parentheses in original].

Her 196 paragraphs did not approach Chief Justice Fraser's 337 paragraphs in length, however. 
smoking has no useful purpose. The Court found that it had been proven to be universally harmful to health with no redeeming characteristic. That it chose not to criminalize smoking does not alter the fact that encouraging young people and others to smoke is a separate, definable, and culpable act. ${ }^{\text {is }}$

The federal Government's alternative "peace, order and good government" argument was summarily rejected by the dissenters because

[t]he regulation of ordinary firearms does not have either the necessary "singleness, distinctiveness and indivisibility" to distinguish it from matters of provincial concern, or a scale of impact on provincial jurisdiction that it is reconcilable with the fundamental distribution of power under the Constitution. It is not a new subject matter, nor is it one on which the provinces are incapable of legislating effectively. Peace, order and good government, in my respectful view, is a constitutional red herring. ${ }^{16}$

These conclusions, both majority and dissenting, are unremarkable in terms of constitutional principle. Their disagreement is primarily the product of sharply discrepant perceptions as to the purpose and effect of the particular legislative scheme; and those differing perceptions are probably rooted, despite disclaimers on both sides, in the judges' personal views about the desirability of gun control legislation.

\section{RICOCHETS}

Of greater interest to students of constitutional law are general observations made by Chief Justice Fraser, apparently concurred in by Berger J. and by the two dissenters, concerning the general approach to be adopted in the analysis of division of powers questions and, in particular, the contributions thereto of the "pith and substance" principle. I turn to those observations next.

There are two aspects of Chief Justice Fraser's lengthy excursus on "pith and substance" that cause me concern. Both are subtle points. It may help to begin with an outline of the traditional approach as I understand it.

All authorities seem to agree that the courts' task in resolving division of powers disputes involves two stages, which are deceptively easy to describe:

(a) determine the "matter" of the impugned legislation: what it is basically about; and

Supra note 2 at para. 536.

Ibid. at para. 444. It is tempting to undertake a critique of this holding, which seems incompatible with the majority decision in $R$. v. Crown Zellerbach, [1988] I S.C.R. 401, and appears to misconstrue the "provincial inability" test for determining the applicability of the "POGG" power. (See: D. Gibson, "Measuring National Dimensions - The Federal Peace, Order and Good Government Power" (1976) 7 Man. L.J. 15.) However, since POGG did not loom large in the Court of Appeal decision, and is unlikely to do so before the Supreme Court of Canada, the temptation will be resisted. 
(b) decide whether that matter falls within a "class of subject" assigned to the enacting legislature by the Constitution. ${ }^{17}$

The same authorities acknowledge, and both the majority and dissenters in the Firearms Reference ${ }^{18}$ accepted, that, as Justice Conrad put it, "it is difficult to avoid blurring the lines between the ascertainment of the 'matter' and the 'class of subjects' into which it falls." This is so because the designation of "matter" is not made in a vacuum; it is inevitably made in the knowledge that the choice will often dictate the relevant "class of subject." For example, the "matter" of the licensing/registration provisions under attack could be characterized as either:

(a) promotion of public safety by reducing the harm caused by the misuse of firearms (the federal Government's position); or

(b) control of the ownership, possession and lawful use of firearms (the challengers' position).

Theoretically, the court then asks whether the "matter" selected falls into the "class of subject" upon which the proponents of the provisions are relying: "criminal law" in this case. In the early days of Canadian constitutional interpretation, the outcome of this second analytical stage could be difficult, and sometimes, in novel situations, it still is. For the most part nowadays, however, with a large body of case law about the ambit of the various "classes of subjects" available, the "matter" decision virtually determines the "subject" decision. In the case at hand, if the "matter" propounded by the federal Government ("public safety") were accepted, the subject of "criminal law" would be indicated, because the case law long ago established that conduct prohibited with penal consequences for reasons that include the protection of public safety is "criminal" for constitutional purposes. If, on the other hand, the challengers' characterization ("ownership control") were preferred, the "criminal law" power would not be applicable because ownership, possession, and lawful use of property are not "criminal" in nature.

Courts are greatly assisted in carrying out this classification task by the "pith and substance" principle: that the "matter" of the challenged legislation consists only of its essential features, its real substance, rather than its form or ancillary characteristics.

It is not always recognized that the "pith and substance" notion has two distinct applications. The first distinguishes substance from form, and enables courts to "pierce the veil" of legislative language, throwing aside pretence and characterizing laws by their true functional significance. Both Chief Justice Fraser for the majority and Justice Conrad in dissent referred to this application of "pith and substance" as the "colourability" doctrine. ${ }^{19}$ The latter term has been customarily applied only to 
deliberate legislative subterfuges. ${ }^{20}$ Substance has long been given priority over form even in the absence of ulterior motive, however, so perhaps no great harm is done by extending the term "colourable" to legislation having an unintended impact of substance that is not obvious on its face.

The other meaning of the "pith and substance" approach is that only key characteristics are taken into account when the "matter" is being determined, minor, incidental features being disregarded. ${ }^{21}$ As Professor Hogg has said: "[I]t is necessary to identify the dominant or most important characteristic of the challenged law."22

It should be noted that what is crucial here is the dominant characteristic of the "challenged law," rather than of the topic with which the legislation deals. This distinction is no semantic quibble since the "dual aspect" principle permits the same topic to be dealt with by both federal and provincial legislation, provided that each law concerns, in pith and substance, a "class of subject" within the competence of the enacting legislature. To illustrate: the topic of "firearm registration" may be dealt with by both federal legislation whose purpose and effect serve essentially criminal goals (e.g.: prohibiting the possession of unregistered guns in the interests of public safety); and provincial legislation whose purpose and effect serve essentially civil goals (e.g.: requiring the registration of guns, like the registration of cars, in the interests of orderly firearm sales, insurance requirements, and so on). Both federal and provincial laws, relating in pith and substance to classes of subject within their respective legislative jurisdictions, could exist side-by-side (unless they conflicted operationally, in which case the "federal paramountcy" principle would give the nod to the federal statutes).

Both the purpose and effect of a law are relevant to determining its pith and substance. An improper purpose (such as a Criminal Code provision primarily intended to regulate the ownership of property) would clearly invalidate the law, but so would an unintended but substantial "out of bounds" effect (such as a Criminal Code provision designed to punish criminal behaviour, but having the inadvertent consequence of interfering substantially with property ownership). ${ }^{23}$

Chief Justice Fraser's Reasons for Judgment include a scholarly and close to exhaustive discussion of these general principles. While one wonders why so elaborate an analysis was considered necessary in a case as relatively straightforward as this, the discussion is informative and insightful, and could well become a locus classicus on

In the Alberia Bank Tax Reference, [1939] A.C. 117 (P.C.), for example, legislation which purported to place a direct tax on banks operating within the province was struck down becausc the true purpose of the legislation was held to be to drive banks out of the Province, rather than raise tax revenues.

In Russell v. R. (1882), 7 App. Cas. 829 (P.C.) [hereinafter Russell], for example, federal temperance legislation that incidentally affected the licensing of taverns within the province and the civil right of tavern-keepers to carry on their business and sell their wares, both of which matters were within provincial jurisdiction, was upheld because the legislation was not held to be about those provincial matters in pith and substance.

$23 \quad$ Ibid. at 15-12 to 15-16. 
the subject. It is because of the prospect that her Reasons may be drawn upon by future courts that I offer criticisms of two small but significant points in Chief Justice Fraser's analysis. Although neither point affected her conclusions, the possibility that they could be perpetuated in future cases suggests that they are worthy of comment.

The first (and lesser) of the points concerns the respective contributions of purpose and effect to division of powers analysis. Although Chief Justice Fraser acknowledged that both factors are relevant, ${ }^{24}$ the role she assigned to effect was unduly narrow, in my view. Those who challenged the legislation had contended that it is "colourable" because it will not, in their view, effectively achieve the criminal law purposes it is intended to serve. In the words of the Chief Justice:

[T] The Provinces are convinced that the legislation is flawed since there is no compelling evidence that requiring law-abiding members of the community to register their guns will have any meaningful impact on crime.

What the Provinces effectively invite this Court to do is to place the efficacy of the impugned legislation on the division of powers scale. ${ }^{25}$

She correctly rejected this argument, stating that "[m]erely because Parliament could have chosen a more effective way to accomplish its purposes does not make the challenged legislation colourable."26 She went on to say that although "practical effect is ordinarily not the best barometer to use in determining pith and substance," ${ }^{27}$ it is relevant to the extent of showing "whether the effects reveal a demonstrable connection between the ascertained purpose of the impugned provisions and the means chosen to implement it." 28 If this was intended to suggest that effect is only relevant to show a plausible link between purpose and means, it seems rather too narrow. Even if the legislative measures chosen were demonstrably connected to the lawmakers' intended purpose, a court could strike the legislation down on the basis of unintended effects on some class of subject within the jurisdiction of the other order of government if those effects outweighed the intended ones in impact. If, to choose a fanciful example, the federal gun registration laws were so onerous as to cause large numbers of Canadian sports hunters to hunt clandestinely, because of concern that acquiring a hunting license would "tip off" firearms officers, that unintended effect might induce a court to find that the legislation is in pith and substance about hunting - a subject within provincial jurisdiction.

My other concern about Chief Justice Fraser's analysis is more serious, though no less difficult to explain. It relates to the process of "weighing" the respective federal

$\begin{array}{ll}24 & \text { Supra note } 2 \text { at para. } 135 . \\ 25 & \text { Ibid. at paras. } 132 \text { and } 134 . \\ 24 & \text { Ibid. at para. } 135 . \\ 27 & \text { Ibid. } \\ 2 \mathrm{n} & \text { Ibid. at para. } 136 .\end{array}$


and provincial ramifications of the legislation. As explained above, this balancing should occur in the context of the challenged law (Firearms Act provisions about gun registration and licensing), rather than of the topic involved (gun registration and licensing generally). In some portions of her Reasons for Judgment, Chief Justice Fraser seemed to acknowledge that. ${ }^{29}$ Other portions, however, could be construed as suggesting that the entire topic of gun registration/licensing is either exclusively federal or provincial in pith and substance, depending on the respective weights of the federal or provincial "interests." For example: "the Provinces must establish that the provincial interests in the subject [of] firearms licensing, registration and prohibition provisions outweigh the federal interests." 30

If this caused the reader to conclude that only the jurisdiction with the greatest overall interest in a topic could make laws about it, it would be misleading. As explained previously, the "dual aspect" principle allows both orders of government to make laws about the same subject for their own distinct purposes, regardless of the respective importance of those purposes. The courts established many years ago, for example, that both the Parliament of Canada and provincial Legislatures may enact local option temperance legislation for their respective purposes. ${ }^{31}$

These two small concerns about Chief Justice Fraser's general explanation of the "pith and substance" principle do not impugn in any way the validity of the conclusions she and her majority colleagues reached concerning the Firearms Act. It seems likely to me that, when the "division of powers" attack is carried back to the Federal Government's Ottawa homestead, the Supreme Court of Canada lawmen and lawwomen will repulse it even more decisively than their Court of Appeal deputies did.

\section{POSSIBLe FUtURE Raids}

That does not mean, however, that the legislation will necessarily live happily and uncontested ever after. Future assaults, employing altogether different constitutional weapons than those used in the present reference, continue to be real possibilities. Among the weapons that could possibly be deployed successfully are Aboriginal rights under s. 35 of the Constitution Act, 1982, and equality rights under s. 15 of the Canadian Charter of Rights and Freedoms.

\section{ABORIGINAL RIGHTS}

Section 35(1) of the Constitution Act, 1982 guarantees that: "[t]he existing aboriginal and treaty rights of the aboriginal peoples of Canada are hereby recognized and affirmed." It would not be surprising if an Aboriginal person or group who considered firearm licensing and registration to be an interference with their Aboriginal or treaty right to hunt claimed a "constitutional exemption" from the application of the Firearms Act on the basis of s. 35(1). The use of firearms is certainly integral to the exercise of

Ibid. at para. 21.

Ibid. at para. 48 [emphasis added].

Russell, supra note 21. 
hunting rights. It also seems clear that modern hunting methods are protected by s. 35 , since, as the Supreme Court of Canada stated in $R$. v. Sparrow, its first ruling on the meaning of s. 35 :

[T]he phrase "existing aboriginal rights" must be interpreted flexibly so as to permit their evolution over time. To use Professor Slattery's expression ... the word "existing" suggests that those rights are "affirmed in a contemporary form rather than in their primeval simplicity...."

The Firearms Act contains a provision, s. 2(3), that looks like an attempt to circumvent Aboriginal rights problems:

For greater certainty, nothing in this Act shall be construed so as to abrogate or derogate from the existing aboriginal or treaty rights of the aboriginal peoples of Canada under $\mathrm{s} .35$ of the Constitution Act, 1982.

That provision does not resolve much, however, since an Aboriginal claimant who attempted to rely on its protection would face precisely the same task as if s. 35 were relied on directly in the absence of the legislative provision: to prove the violation of an Aboriginal right. The unhelpfulness of such legislative devices has been pointed out from the bench on more than one occasion. ${ }^{33}$

If an Aboriginal rights claim were advanced against the Firearms Act, the key to its success would be whether the registration and licensing of firearms constitutes valid "regulation" of the Aboriginal right to hunt. Although s. 35(1) expresses the right in absolute terms (apart from the adjective "existing," which does not seem relevant here), free from an explicit "reasonable limits" proviso such as that which s. 1 of the Charter imposes on all Charter rights, the Supreme Court of Canada's decision in Sparrow held that an exception analogous to s. 1 of the Charter is implicit. That inference seems to have been based on the fact that s. 35 merely says Aboriginal rights are "recognized and affirmed" (in apparent contradiction to "guaranteed" Charter rights):

In response to the appellant's submission that s. 35(1) rights are more securely protected than the rights guaranteed by the Charter, it is true that s. 35(1) is not subject to s. 1 of the Charter. In our opinion, this does not mean that any law or regulation affecting aboriginal rights will automatically be of no force or effect by the operation of s. 52 of the Constitution Act, 1982. Legislation that affects the exercise of aboriginal rights will not the less be valid, if it meets the test for justifying an interference with a right recognized and affirmed under s. 35(1).

There is no explicit language in the provision that authorizes this court or any court to assess the legitimacy of any government legislation that restricts aboriginal rights. Yet, we find that the words "recognition and affirmation" incorporate the fiduciary relationship referred to earlier and so import some restraint on the exercise of sovereign power. Rights that are recognized and affirmed are not 
absolute. Federal legislative powers continue, including, of course, the right to legislate with respect to Indians pursuant to s. 91(24) of the Constitution Act, 1867. These powers must, however, now be read together with s. 35(1). In other words, federal power must be reconciled with federal duty and the best way to achieve that reconciliation is to demand the justification of any government regulation that infringes upon or denies aboriginal rights. Such scrutiny is in keeping with the liberal interpretive principle enunciated in Nowegijick, supra, and the concept of holding the Crown to a high standard of honourable dealing with respect to the aboriginal peoples of Canada as suggested by Guerin v. The Queen, supra.

We refer to Professor Slattery's "Understanding Aboriginal Rights,", ibid., with respect to the task of envisioning a s. 35(1) justification process. Professor Stattery, at p. 782, points out that a justificatory process is required as a compromise between a "patchwork" characterization of aboriginal rights whereby past regulations would be read into a definition of the rights, and a characterization that would guarantee aboriginal rights in their original form unrestricted by subsequent regulation. We agree with him that these two extreme positions must be rejected in favour of a justificatory scheme. ${ }^{34}$

If this reasoning seems less than compelling logically, it undoubtedly makes sense in terms of the realpolitik that often trumps logic in constitutional decision-making. ${ }^{35}$

Having determined in Sparrow that some form of "justificatory scheme" is implicitly called for, the Court then proceeded to fashion one. While cautioning that "the contours of a justificatory standard must be defined in the specific factual context of each case,"36 it outlined a general two-step approach which, although rough-hewn, is likely to guide future decisions. First, the rights-claimant must establish that there has been an unacceptable interference with an Aboriginal right:

The first question to be asked is whether the legislation in question has the effect of interfering with an existing aboriginal right....

To determine whether the ... rights have been interfered with such as to constitute a prima facie infringement of s. 35(1), certain questions must be asked. First, is the limitation unreasonable? Secondly, does the regulation impose undue hardship? Thirdly, does the regulation deny to the holders of the right their preferred means of exercising that right? The onus of proving a prima facie infringement lies on the individual or group challenging the legislation. ${ }^{37}$

Once the rights claimant has established a prima facie violation, the onus shifts to the Crown:

Supra note 32 at 409.

D. Gibson, "The Real Laws of the Constitution" (1990) 28 Alberta L.R. 358.

Supra note 32 at $\mathbf{4 1 0 .}$

Ibid. at 411 . Those comments were made in respect of Aboriginal fishing rights, but it is not likely that a different general approach would be adopted for other Aboriginal rights. 
If a prima facie interference is found, the analysis moves to the issue of justification. This is the test that addresses the question of what constitutes legitimate regulation of a constitutional aboriginal right. The justification analysis would proceed as follows. First, is there a valid legislative objective? Here the court would inquire into whether the objective of Parliament ... is valid. The objective of the department in setting out the particular regulations would also be scrutinized. ${ }^{38}$

\section{The Court offered the following examples of valid objectives:}

An objective aimed as preserving s. 35(1) rights by conserving and managing a natural resource, for example, would be valid. Also valid would be objectives purporting to prevent the exercise of s. 35(1) rights that would cause harm to the general populace or to aboriginal peoples themselves, or to other objectives found to be compelling and substantial. ${ }^{39}$

Even if the objectives of the legislation and regulations are valid, the Crown must show that they cannot be met without sacrificing the priority of Aboriginal rights:

If a valid legislative objective is found, the analysis proceeds to the second part of the justification issuc.... The special trust relationship and the responsibility of the government vis-à-vis aboriginals must be the first consideration in determining whether the legislation or action in question can be justified.

The constitutional nature of the Musqueam food fishing rights means that any allocation of priorities after valid conservation measures have been implemented must give top priority to Indian food fishing.

The constitutional entitlement embodied in s. 35(1) requires the Crown to ensure that its regulations are in keeping with that allocation of priority. ${ }^{40}$

The Crown must also show that the measures taken satisfy what, in a Charter context, would be called the "minimal impairment" test:

Within the analysis of justification, there are further questions to be addressed, depending on the circumstances of the inquiry. These include the questions as to whether there has been as little infringement as possible in order to effect the desired result."

Applying these "justificatory standards" to the Firearms Act causes me to conclude that Aboriginal persons are probably entitled to a constitutional exemption from its registration and licensing provisions in respect to firearms used by Aboriginal persons in the exercise of their s. 35(1) hunting rights. Requiring such persons to undergo

Ibid. at 412 .

Ibid.

Ibid. at 413,414 , and 416 .

Ibid. at 416 . 
bureaucratic processes that have little relevance to their communities or their way of life before they may use tools that are essential to exercising their Aboriginal right, will probably be found "unreasonable" and "undue hardship." While the courts are likely to find that those processes were enacted pursuant to the "valid legislative objective" of maximizing public safety by minimizing firearm abuses, the basically urban nature of the problem suggests that applying the measures to guns used in the pursuit of Aboriginal or treaty rights is an unnecessary and far from minimal impairment of that right. To put the point another way, the "valid objectives" of the Firearms Act would not be unduly compromised by according "top priority" to Aboriginal rights by means of a constitutional exemption from the legislation for the holders of those rights.

\section{EQUALITY RIGHTS: GEOGRAPHIC DISCRIMINATION}

\section{Section 15(1) of the Canadian Charter of Rights and Freedoms states:}

Every individual is equal before and under the law and has the right to the equal protection and equal benefit of the law without discrimination and, in particular, without discrimination based on race, national or ethnic origin, colour, religion, sex, age, or mental or physical disability.

I believe a good argument can be made to the effect that equality does not exist before and under the law for residents of Yukon, Northwest Territories, Nunavut, and perhaps the northern areas of most provinces as well. This is not because the Firearms Act singles those areas out for special attention, but because it does not do so. The reliance of northerners and other rural residents on firearms as an important part of their everyday lives means that the Firearms Act has a disproportionately adverse impact on them in comparison with other Canadians. This form of inequality, known as "systemic discrimination," has been held to be prohibited by s. 15 of the Charter, even when it is unintentional:

It is not a question of whether this discrimination is motivated by an intentional desire to obstruct someone's potential, or whether it is the accidental by-product of innocently motivated practices or systems. If the barrier is affecting certain groups in a disproportionately negative way, it is a signal that the practices that lead to this adverse impact may be discriminatory. ${ }^{42}$

Professor Peter Hogg has described systemic discrimination in this way: "A law that is neutral (non-discriminatory) on its face may operate in a discriminatory fashion; if it does, the discrimination is systemic." ${ }^{43}$ The present writer explained it as follows in a previous publication: citing "Abella Report on Equality in Employment" as cited in Action Travail des Femmes v. CNR (1987), 40 D.L.R. (4th) 193 (S.C.C.), Dickson C.J.C. 
Discrimination can be said to be "systemic" if it is a consequence of the manner in which some general system is organized or operated, rather than of particularized action directed at specific individuals or groups. ${ }^{4}$

The Supreme Court of Canada's recognition that "systemic" or "adverse impact" discrimination is proscribed by s. 15 of the Charter began with its first ruling on s. 15, the Andrews case, where McIntyre J. stated for the entire Court, that: "a law expressed to bind all should not because of irrelevant personal differences have a more burdensome or less beneficial impact on one than another." ${ }^{\text {"45 }}$

Justice McIntyre explained in Andrews that "equality" and "sameness" are not necessarily the same thing:

It must be recognized at once, however, that every difference in treatment between individuals under the law will not necessarily result in inequality and, as well, that identical treatment may frequently produce serious inequality. ${ }^{\text {th }}$

This has been understood, he pointed out, since at least the time of Aristotle, who explained the principle of equality as follows: "[T]hings that are alike should be treated alike, while things that are unalike should be treated unalike in proportion to their unalikeness." 47

The adverse impact principle was re-affirmed by the Supreme Court of Canada in Symes v. Canada, where Iacobucci J. stated for the Court (unanimous as to the principle, though not as to its application in that case): "it is clear that a law may be discriminatory even if it is not directly or expressly discriminatory. In other words, adverse effects discrimination is comprehended by s. 15(1)." ${ }^{, 48}$

The registration and licensing provisions of the Firearms Act, though nondiscriminatory on their face, comprise a system which disproportionately impacts on the ability of northerners and other rural residents to live their lives the way they and their predecessors have lived since before non-Aboriginal settlement of those areas began. Intended to deal with problems relating to the criminal use of firearms that are primarily endemic to the urban areas of southern Canada, the registration and licensing provisions of the legislation are made applicable to the entire country, including those areas where the justifiable use of firearms for sustenance and recreation has always been, and remains, an important and safe part of everyday life; and where application of those provisions will be much more difficult and onerous than in the urban areas for which they were designed. That may well be found to constitute "systemic" or "adverse effects" discrimination, contrary to s. 15(1) of the Charter.

D. Gibson, The Law of the Charter - Equality Rights (Toronto: Carswell, 1990) at 119. Supra note 42 at 11.

Ibid. at 10.

lbid. at 11 [emphasis added].

(1993), 110 D.L.R. (4th) 470 at 552 (S.C.C.). 
The disproportionately negative impact on northerners of the regulatory scheme established by the Firearms Act was expressed by the Honourable Doug Phillips, 9 May 1995 in his submission on behalf of the Yukon Government to the House of Commons Standing Committee on Justice and Legal Affairs (Meeting No. 129). A few selected passages from that submission make the point:

An Angus Reid poll indicates that $67 \%$ of Yukoners own firearms as compared to $23 \%$ in southern Canada. Such a high rate of ownership in Yukon leads to a population that is very knowledgable about firearms and how to use them responsibly and safely....

Yet high levels of ownership alone do not fully account for the way Yukoners react to the Bill. At the heart of our opposition is the feeling that a shared set of fundamental values is under attack. These values are what help define what the Yukon is, and shape the identity of who Yukon people are. Throughout the Yukon's history, both before the arrival of Europeans and after, the Yukon's wilderness and wildlife have been the dominant themes of Yukoners' lives. Since the introduction of firearms to the territory hundreds of years ago, firearms have been inextricably intertwined with these themes.

As such, firearms are perceived very differently from the way they are in other parts of the country. In the Yukon they are necessary tools, heirlooms, or dependable companions on trips into the wilderness. It is still not hard to find people in the Yukon who will entertain you with stories of how firearms saved a life, perhaps when meeting a bear while working a remote placer mine, or when charged by a moose while running a team of dogs. This is very different from the south, where firearms are, to the vast majority of people, the weapons of criminals.

[T] he Yukon does not have a problem with the illegal use of firearms in the same way as does southem Canada, and the statistics bear this out. Crime statistics show that serious offences involving firearms, such as armed robbery and assault with a firearm, are few in number... In 1994 there were 2 armed robberies in the Yukon, and one assault involving a firearm. The Yukon also has few homicides committed with firearms. Between 1986 and 1994 there were 10 homicides in the Yukon, of which 3 were committed with firearms.... There is no evidence to suggest that any of these three homicides would have been prevented if a universal registration system had been in place at the time.

Implementing universal registration in the Yukon could cost $\$ 500,000$ or more. Spending this amount of money on a system which will have very little effect on only a handful of firearms related crimes is indefensible...."

Many provisions of the Firearms Act have a "disparate impact" in the north simply because conditions prevailing there differ sharply from those which prevail in the

4) Canada, House of Commons, Proceedings of Standing Committee on Justice and Legal Affairs, \#129, (Ottawa: House of Commons, 1995) at 3, 16. 
southern parts of the country which the drafters of the legislation obviously had in mind when it was being formulated. Some examples of this special impact on the north include: the peculiar difficulties of providing satisfactory firearms courses (as required by s. $7(1)$ ) in remote areas; the great difficulty in many circumstances that northerners would have in complying with the requirement under s. 94 of the amended Criminal Code to leave a vehicle after learning that it contains an unregistered or unlicensed firearm; the potential criminal liability for failure to comply with licensing and registration includes an offence for possession of an unregistered firearm (s. 112); and amendments to ss. 91 and 92 of the Criminal Code which make it an offence to fail to comply with the licensing and registration system. All these provisions present serious implementation difficulties in respect of the vast territory and scattered populations of the north. Even more important than such particular examples is the fact that the entire scheme for licensing and registering firearms and their users is inappropriate for the north and other parts of Canada where the problems sought to be addressed by the legislation do not exist, and where the implications of applying the scheme are especially onerous.

While the above-quoted submissions of Mr. Phillips were made in relation to Yukon in particular, they are equally applicable to other parts of Canada as well. This is obviously the case for the Northwest Territories and Nunavut, and it is also so for the northern parts of most provinces in which lifestyles similar to those of the territories prevail. Establishing the extent to which they apply to other rural parts of the provinces would require more evidence than we have currently at hand, so the remainder of this comment will be restricted to the situation of the territories.

Geographically disparate application of laws has been held to be a denial of "equality before the law" within the meaning of s. 15 of the Charter. In $R$. v. Turpin, for example, the Supreme Court of Canada concluded that an accused had been denied equality before the law on a geographic basis, stating: "The guarantee of equality before the law is designed to advance the value that all persons be subject to the equal demands and burdens of the law and not suffer any greater disability in the substance and application of the law than others." ${ }^{50}$ The Court held in that case that accused persons in Ontario were denied equality before the law because they did not have the same right to trial by judge alone, without jury, as Albertans charged with the same offence had by reason of a special Criminal Code provision that was applicable only to Alberta:

[T]he impugned provisions of the Criminal Code treat the appellants ... more harshly than those charged with the same offences in the province of Alberta ... I would conclude, therefore, that the appellants' right to equality before the law has been violated. ${ }^{51}$

The claimants ultimately lost their appeal on the basis of the "discrimination" issue, which will be examined next, but the Court had no difficulty determining, unanimously, 
that the geographic distinction created by that legislation denied equality before the law.

Discrimination contrary to the Charter occurs when someone is denied equality before or under the law, or equal benefit or protection of law, on the basis of one of the criteria specified in s. 15 of the Charter ("race, national or ethnic origin, colour, religion, sex, age or mental or physical disability"), or of an "analogous" ground. Since "place of residence" is not one of the grounds of discrimination expressly mentioned in s. 15, the detrimental treatment of northerners by the Firearms Act could only be challenged under the Charter if "place of residence" qualified as an analogous ground. There is good reason to believe that it does, though only in restricted circumstances.

The Supreme Court of Canada has found the following to be analogous grounds: citizenship; $^{52}$ sexual orientation; ${ }^{53}$ marital status; ${ }^{54}$ and Aboriginality-residence. ${ }^{55}$ The latter decision, quite recent, offers strong encouragement to those who believe that some geographic discrimination is prohibited by s. 15 . Before examining that case, however, it may be useful to survey the preceding jurisprudence.

Not long after s. 15 of the Charter first came into force in 1985, it was held to include geographic discrimination in decisions striking down legislation that restricted the size of juries in the Northwest Territories to six persons. ${ }^{36}$

The Supreme Court of Canada's first consideration of a geographic discrimination claim under the Charter, however, was less encouraging. Turpin addressed a special provision of the Criminal Code allowing persons accused of certain offences in Alberta to elect a judge alone trial, though this option was not available to non-Albertans. The Court accepted that an accused who was refused trial by judge alone because he lived in Ontario rather than Alberta had been denied equality before the law, but held that this denial did not constitute "discrimination."

Wilson J., writing for a unanimous Court in that case, said that, in determining whether an unlisted ground of discrimination is "analogous," it is necessary to look to the "larger social, political, and legal context," as well as to "the place ... in the entire social, political and legal fabric of our society" of the group affected by the alleged discrimination. In defining the group affected in that case, Wilson J. classified it as those people accused of s. 427 offences under the Criminal Code in all provinces except Alberta, and found that this was not a historically disadvantaged "discrete and insular minority." However, she went on to point out that each case must be decided on its own facts, and stated:

s2 Andrews, supra note 42.

s3 Egan v. Canada (1995), 124 D.L.R. (4th) 609 (S.C.C.).

s4 Miron v. Trudel (1995), 124 D.L.R. (4th) 693 (S.C.C.) [hereinafter Miron].

ss Corbière v. Canada (1999), 173 D.L.R. (4th) 1 (S.C.C.) [hereinafter Corbière].

s6 R. v. Emile, [1988] N.W.T.R. 196 (C.A.). See also Rafael v. Allison, [1988] I W.W.R. 570 (Alta. Q.B.). 
I do not wish to suggest that a person's province of residence or place of trial could not in some circumstances be a personal characteristic of the individual or group capable of constituting a ground of discrimination. I simply say that it is not so here. ${ }^{57}$

The reasoning of Wilson J. in Turpin was cited with approval in R. v. S.(S.), ${ }^{58}$ which held that the failure of Ontario to proclaim "alternative measures" provisions of the Young Offenders Act did not violate s. 15 of the Charter. It was also cited by L'Heureux Dubé J., writing for the majority in Haig v. Canada ${ }^{59}$ which upheld the residency requirements of the federal legislation governing the referendum held to seek approval of the Charlottetown Accord in 1992. The plaintiff in Haig complained that because the federal legislation did not apply to Quebec, which had its own referendum legislation, and because he had recently moved to Quebec, he did not qualify to vote under either federal or provincial schemes. The Court denied that there had been a violation of s. 15, however, because recent residents of Quebec could not be considered a group analogous to those protected from the forms of discrimination listed in s. 15. In both cases, however, while rejecting place of residence as an analogous ground on the facts, the Supreme Court left the door open to argue that place of residence could be a prohibited ground of discrimination in some circumstances.

In the Haig case, in fact, L'Heureux-Dubé J., for the majority made a comment that is worth considering in relation to applying the Firearms Act to the north:

Territorial exigencies, such as those present in the northern territories, may justify a host of rules particular to a given province, and the possibility of such divergence is woven into the very fabric of Canadian federalism itself. ${ }^{(11}$

While that comment was made to explain why differential treatment of different parts of Canada may not be discriminatory, it may be relevant to the problem at hand when considered in light of the principle that treating unalikes alike can be discriminatory.

None of these Supreme Court pronouncements was conclusive as to geographic discrimination. None went so far as to accept geography as an analogous ground. On the other hand, they did indicate that the Supreme Court is sensitive to the varying needs to which geography gives rise in Canada, and they left open the possibility that on the right set of facts the Court would be prepared to find that place of residence is a prohibited ground of discrimination.

A 1996 decision of the Northwest Territories Court of Appeal, Canadian Egg Marketing Agency v. Richardson, offered less hope. The Charter claimants in that case were egg producers in the Northwest Territories who were prohibited by a federal marketing scheme from selling eggs in interprovincial trade simply because the scheme made no provision for territorial quotas. They challenged the constitutionality of the 
regulatory scheme, alleging violations of the association, mobility, and equality guarantees of the Charter. At trial, they were successful on all three grounds. ${ }^{61}$ The Court of Appeal affirmed that decision on the first two grounds, but rejected the equality claim. ${ }^{62}$ Its rejection of the contention that territorial egg producers were the victims of geographic discrimination was based on two reasons: (i) that place of residence is not an "immutable characteristic," and cannot therefore qualify as an "analogous" ground; and (ii) that "egg producers in the Northwest Territories" are not a "discrete and insular minority" that suffered historically from stereotyping, social prejudice and disadvantage, or political prejudice. A subsequent appeal to the Supreme Court of Canada reversed the Court of Appeal's rulings on freedom of association and mobility rights, but did not address the equality issue because the ruling on that question had not been appealed. ${ }^{63}$

The Court of Appeal's equality decision in the Egg Marketing case does not in my opinion present a serious obstacle to pursuing a "place of residence" discrimination claim in relation to the Firearms Act. This is so for several reasons. For one thing, these conclusions were probably obiter dicta since they concerned an alternative argument that turned out to be unnecessary, given the victory of northern egg producers on other grounds. The judge who wrote the Court's reasons for judgment noted that she dealt "only briefly" with the equality question, "given my earlier conclusions." 64

The conclusion reached as to equality in the Egg Marketing case was, moreover, demonstrably wrong in two key respects. The first error concerned "immutability." The Court found that: "residence is not an 'immutable characteristic' that cannot easily be changed, in the way that LaForest J. found homosexuality to be in Egan...." ${ }^{65}$

The Court seems to have treated this alleged lack of immutability as a conclusive element, overlooking the fact that in Miron $^{66}$ a majority of the Supreme Court of Canada held that immutability, while a sometimes "valid indicator" of discrimination, is not a necessary component of analogous grounds under s. 15. "Immutability" is a relative, rather than an absolute, concept. The Supreme Court has equated it with difficulty of change, rather than impossibility of change. It was introduced to "analogous ground" analysis in order filter out cases of differential treatment based on features as fleeting as dress style or choice of friends. The Egg Marketing decision overlooked the fact that the relatively changeable characteristic of "citizenship" was found to be an analogous ground by the Supreme Court of Canada in Andrews, ${ }^{67}$ and that, in Miron, ${ }^{68}$ the even more changeable criterion of "marital status" was so characterized. "Place of residence" is a characteristic at least as "immutable" as those. "Place of residence" can mean many things, of course, ranging from the particular house or

(1995), 129 D.L.R. (4th) 195 (N.W.T.S.C.).

(1996), 132 D.L.R. (4th) 274 at 305-306 (N.W.T.C.A.) [hereinafter Egg Marketing].

(1998), 166 D.L.R. (4th) 1 (S.C.C.).

Supra note 62 at 304.

Ibid. at 305.

Supra note 54 at 748.

Supra note 42.

Supra note 54. 
apartment one occupies from time to time to the country one lives in. While one's street address, or perhaps even one's city, town, or village, might not be sufficiently "immutable" to satisfy the requirements of s. 15 , residence in a particular region of the country, especially the north, could undoubtedly be shown to be as relatively permanent a factor as "citizenship," and much more so than "marital status."

The Northwest Territories Court of Appeal's rejection of the equality claim in the Egg Marketing case also displayed a mistaken approach to the "discrete and insular minority" question. The reason that factor was considered relevant by the Court of Appeal is that the Supreme Court of Canada had indicated in earlier cases, notably Turpin, that those who seek the protection of the Charter from discrimination on an "analogous" ground should establish their membership in a victim group that has been historically discriminated against on that ground. A majority of the Supreme Court made it clear in Miron, ${ }^{69}$ however, that this is not an "essential" ingredient of analogousness. While certain catch-phrases, such as "historically disadvantaged groups," or "discrete and insular minorities," possessing "immutable" characteristics, may be indicators of an analogous group, they are only analytical tools and not the end of the analysis. According to McLachlin J., the test remains, in the final analysis, the general and flexible criterion of "analogousness." Despite this authoritative pronouncement that the "discrete and insular minority" test is not an absolute requirement, the N.W.T. Court of Appeal appears to have treated it as such in the Egg Marketing case.

The Federal Court of Appeal recently dismissed a claim of geographic discrimination in Moxham v. Canada. ${ }^{70}$ A person injured in Saskatchewan by a motor vehicle driven by a federal government employee attempted to sue the federal Crown but was met with the defence that Saskatchewan's no-fault automobile insurance legislation prohibits tort litigation arising from motor vehicle accidents. The plaintiff's claim that he was the victim of geographic discrimination, because he could have sued the Crown if the accident had occurred in some other provinces, was rejected by the Federal Court of Appeal on the ground that the Saskatchewan statute treated all accident victims alike throughout the province. That ruling does not appear relevant to the Firearms $A c t$ problem, however, since it related to a provincial statute that was universally applicable throughout the province, rather than to a federal statute alleged to have disparate impact in different parts of the country.

The Supreme Court of Canada's most recent pronouncement on geographic discrimination, Corbière," appears, on the other hand, to be both highly relevant and highly suggestive that geographic disparities might support a successful s. 15 attack on the Firearms Act. That case involved a provision of the Indian Act which denied the right to vote in band elections to band members who were not ordinarily resident on the reserve in question. The Supreme Court of Canada was unanimous in striking the 
provision down on the ground that it discriminated, contrary to s. 15, on the analogous ground of "Aboriginality-residence."

Nothing in the Corbière decision suggests that all geographically-based discrimination is analogous to those forms of discrimination explicitly prohibited by $\mathbf{s}$. 15. In fact, McLachlin J., who wrote for five members of the Court, was careful to deny that suggestion explicitly:

[R]eserve status should not be confused with residence. The ordinary "residence" decisions faced by the average Canadians should not be confused with the profound decisions Aboriginal band members make to live on or off their reserves, assuming choice is possible. The reality of their situation is unique and complex. Thus no new water is charted, in the sense of finding residence, in the generalized abstract, to be an analogous ground. ${ }^{72}$

On the other hand, the decision must have some significance extending beyond the precise fact situation it involved. I think it can be reasonably generalized to mean that geographically-based differential treatment coupled with the type of disadvantage and indignity historically experienced by off-reserve Indians and other discrimination victims constitutes "analogous" discrimination.

Turning back to the situation at hand, I believe a strong case can be made to the effect that the Firearms Act discriminates against northerners on the analogous ground of "northern residence." Residents of Canada's remote north have always been, and continue to be, uniquely disadvantaged because of their location. Quite apart from the rigours of their climate, residents of the northern territories have access to fewer, and often less satisfactory, public services than residents of the south; their economic situation is decidedly less advantageous than that of southerners; and they have the severe political disadvantage that the ultimate responsibility for their governance lies in far-away Ottawa. There are some offsetting advantages, of course; many northerners choose to live where they do because they like the freedom and the closeness to nature that typifies the northern lifestyle. To be required to comply with registration and licensing requirements that are generally unnecessary in the north, that have a greater detrimental impact on northerners than on southerners, and that thereby derogate from the freedom northerners have always savoured, is to be discriminated against on the basis of northern residence.

One element commonly associated with discrimination that has not yet been discussed is "stereotyping." Historically, much discrimination has sprung from negative stereotypes harboured by members of the majority about particular minorities. Although the Andrews decision did not refer to the concept of stereotyping, it was introduced by Wilson J. in Turpin when she referred to: "indicia of discrimination such as stereotyping, historical disadvantage or vulnerability to political and social prejudice." ${ }^{\text {?3 }}$ 
It will be noted that stereotyping was there described as only one of several "indicia." In Miron, however, McLachlin J., writing for the majority of the Supreme Court, seemed to say that although factors such as "immutability" and "historical disadvantage" are "inclusionary" rather than crucial elements, stereotyping is a sine qua non:

All these and more may be indicators of analogous grounds, but the unifying principle is larger: the avoidance of stereotypical reasoning and the creation of legal distinctions which violate the dignity and freedom of the individual, on the basis of some preconceived perception about the attributed characteristics of a group rather than the true capacity, worth or circumstances of the individual. ${ }^{74}$

In Corbiere, the Supreme Court was unanimous in finding that denying the vote to offreserve band members involved stereotyping. ${ }^{75}$

How can the notion of "stereotyping" be applied to situations of "systemic" or "adverse impact" discrimination? As commonly understood, stereotyping involves conscious attitudes about minorities, and conduct fully intended to reflect those attitudes while systemic discrimination often occurs without either intention or awareness on the part of the discriminator. If that kind of stereotyping were the "unifying principle" for all forms of discrimination under s. 15, then systemic discrimination would not violate s. 15; yet, as indicated earlier, the Supreme Court has consistently said that systemic discrimination is prohibited by s. 15 of the Charter.

There are two possible solutions to this puzzle. One would be that the notion of stereotyping applies only to situations of direct discrimination, like that involved in Miron itself, and is not relevant to cases of "systemic" or "adverse impact" discrimination, like that with which we are concerned here. A more straightforward solution would be that "stereotypes" include ignorance of minority-group characteristics that call for treating the minority differently than the majority. In other words, it is stereotyping to assume, as the drafters of the Firearms Act did, that what is good for the urbanized south is also good for the Northwest Territories, Yukon, and Nunavut. Although it is hard to say which of these approaches the courts might opt for, I doubt that the "stereotype" factor would prevent a Firearms Act challenge based on systemic discrimination against northern residents.

I think such an argument would stand a good chance of success. The Firearms Act imposes on the residents of northern Canada registration and licensing provisions which, though possibly appropriate for the urban areas of the south, seem entirely unsuitable beyond those areas. McIntyre J. noted in Andrews that Frankfurter J. of the United States Supreme Court once observed: "[i]t was a wise man who said that there is no greater inequality than the equal treatment of unequals." 76 
Legislation based on the assumption that firearms uses, abuses, and needs are the same in the north as they are in the urban south seems like a classic illustration of such inequality.

\section{CONCLUSION}

When the smoke clears after the upcoming shoot-out at the S.C.C. Ranch, I expect the federal posse to be still standing its ground. It will remain vulnerable, however, to future attack by Indian war parties, and if the federal marshals are ever called upon to defend the application of the Firearms Act to the northern territories, I am not optimistic about their chances of success. 